\title{
Chronic Granulomatous Disease; fundamental stages in our understanding of CGD Tracy Assari*
}

Address: Molecular Immunology Unit, The Institute of Child Health, University College London and Great Ormond Street Hospital for Children NHS Trust, 30 Guilford Street, London WC1N 3EH, UK

Email: Tracy Assari* - t.assari@ich.ucl.ac.uk

* Corresponding author

Published: 21 September 2006

Medical Immunology 2006, 5:4 doi:I0.1 I86/1476-9433-5-4

This article is available from: http://www.medimmunol.com/content/5/l/4

(c) 2006 Assari; licensee BioMed Central Ltd.

This is an Open Access article distributed under the terms of the Creative Commons Attribution License (http://creativecommons.org/licenses/by/2.0), which permits unrestricted use, distribution, and reproduction in any medium, provided the original work is properly cited.

\begin{abstract}
It has been 50 years since chronic granulomatous disease was first reported as a disease which fatally affected the ability of children to survive infections. Various milestone discoveries from the insufficient ability of patients' leucocytes to destroy microbial particles to the underlying genetic predispositions through which the disease is inherited have had important consequences. Longterm antibiotic prophylaxis has helped to fight infections associated with chronic granulomatous disease while the steady progress in bone marrow transplantation and the prospect of gene therapy are hailed as long awaited permanent treatment options. This review unearths the important findings by scientists that have led to our current understanding of the disease.
\end{abstract}

\section{Early CGD History}

In 1954, at an annual meeting of the Society for Pediatric Research, Janeway and colleagues [1] first reported five cases of children with elevated serum gamma globulin levels that suffered from recurrent infections. At this time, the basis for their susceptibility was not identified. Three years later, four boys with hypergammaglobulinemia, suffering recurrent infections of the lungs, lymph nodes, and skin, with a presence of granulomatous lesions were described by Bridges et al. [2]. Landing and Shirkey [3] also described 2 boys with recurrent infection who had infiltration of visceral organs by pigmented lipid histiocytes. It was here that a new syndrome "fatal granulomatous disease of childhood" was first described. The disease was so called to depict the syndrome of recurrent infections whose sufferers invariably died in the first decade of life. Quie and colleagues further went on to demonstrate the defective bactericidal capacity of the polymorphonuclear leukocytes from affected males, thus meaning that these patients were unable to ward off infections [4]. Over the next ten years little more was known about the disease. Treatments using erythromycin and novobiocin antibiotics, along with regular surgical drainage, increased the survival rate of 4 years to one of 12 years. The use of the word 'fatal' was subsequently dropped from the clinical synonym as patient life expectancy increased with improved medicines and diagnostics, and was classified as the more commonly known chronic granulomatous disease (CGD).

\section{A genetic enzyme disorder}

In the 1960s, studies on patient blood confirmed CGD to be a disease of impaired phagocytes. Holmes et al. [5] suggested that the cellular defect was 'a deficiency in one enzyme, either located within polymorph lysosomes or among those responsible for metabolic adaptations necessary for the normal function of the lysosomes or lysosomal enzymes'. This caused skepticism from some scientists who thought a deficiency of a single enzyme of this type was unlikely and that a less specific factor in the 
phagocytic process was responsible [6]. It was also thought that because the disease occurred in boys and was familial that the defect was X-linked. However, reports of the disease in females began to emerge, thereby revealing an autosomal recessive inheritance of the same phenotype $[7,8]$. It was then that Nathan and Baehner [9] showed that leukocytes from CGD patients, unlike normal human leukocytes, did not reduce nitroblue tetrazolium (NBT), a compound that converts to insoluble blue formazan product upon reduction by the superoxide anion (O2--). This phenomenon was rapidly established as a sensitive clinical screening test for CGD that is still used today.

Over the next twenty years, over 150 scientific papers had been published reporting cases of patients with CGD describing their symptoms and similarities to other granuloma forming diseases. It was observed that CGD leucocytes could ingest micro-organisms but failed to kill the organisms responsible for the infections. Phagocytosis is normally accompanied by a marked increase in oxidative metabolism and studies had shown that NADPH oxidase was the respiratory enzyme responsible for bactericidal activity [10]. The hexose monophosphate shunt is responsible for generating reduced NADPH [10]. The critical deficiency in CGD cells is to generate $\mathrm{O} 2-$ and other reactive oxygen species such as hydrogen peroxide $\left(\mathrm{H}_{2} \mathrm{O}_{2}\right)$ [11]. The importance of $\mathrm{H}_{2} \mathrm{O}_{2}$ was illustrated by the fact that some bacterial species, such as Streptococci, that produces its own $\mathrm{H}_{2} \mathrm{O}_{2}$, could be killed by CGD leucocytes [12]. Following further corroboration that the deficiency in CGD was caused by a defect in the NADPH oxidase system in CGD patients, scientists began to research the formation of the free radical form of oxygen, O2--, produced by NADPH oxidase during its respiratory burst, and showed that whereas normal leucocytes generated O2-during phagocytosis, CGD phagocytes were not able to do this [13-15].

Speculation that a b-type cytochrome may also be involved in this O2-- generating activity began in 1979 from observations that a cytochrome-b associated with a particulate fraction of normal neutrophils, was absent from the neutrophils from some, but not all, patients with CGD [16]. Described as the heme-containing protein, cytochrome- $\mathrm{b}_{558}$ was proposed as a primary component of the microbicidal oxidase system of phagocytes. A multicenter European evaluation of its incidence and relevance was conducted in London [17] where it was found to be undetectable in all 19 of the men studied in whom the defect appeared to be located on the $\mathrm{X}$ chromosome. Thus cytochrome- $\mathrm{b}_{558}$ was hailed an important component of the microbicidal NADPH oxidase system and provided insight into its role in the enzyme complex. Borregaard and colleagues [18] demonstrated that approximately $90 \%$ of the cytochrome- $\mathrm{b}_{558}$ resides in the membrane of the specific granules of unstimulated human neutrophils and that the cytochrome- $b_{558}$ translocates to the plasma membrane when the cells are stimulated. The authors speculated that the observed translocation was essential to the formation of an electron transport chain which generates $\mathrm{O} 2--$, the single precursor from which all microbicidal oxidants ultimately arise.

\section{Unravelling the NADPH oxidase enzyme}

The 1980s saw the formation of a disease-gene relationship. Linkage analysis using cloned, polymorphic DNA probes suggested a proximal location (Xp21) within CGD families [19]. Cytochrome- $b_{558}$ was, so far, the only clearly defined component of this oxidase system and its absence provided the molecular basis of X-linked CGD, in which a profound predisposition to infection resulted from complete failure of this respiratory burst. Within a month of each other in March 1987, three separate groups working on the constituents of the phagocyte NADPH oxidase (phox) enzyme published their findings. Segal was the first to find that cytochrome- $b_{558}$ had two subunits - a $23 \mathrm{~K}$ protein and the previously described 76-92 K glycoprotein. Reporting that the subunits were closely linked and remained associated with the heme of cytochrome$b_{558}$, neither protein was detected in the cells of five patients with X-linked CGD, whereas both were present in two with the autosomal recessive inheritance form of this disease. This was the first finding substantiating what we now know are the smaller and larger subunits of the phagocyte cytochrome- $\mathrm{b}_{558}$ heterodimer (p22phox and gp91phox respectively) [20]. Umei and colleagues then discovered a $66 \mathrm{kDa}$ component [21] particulate in oxidase fractions obtained from patients with CGD, regardless of whether they contained cytochrome- $b_{558}$ or not, and Curnutte and Scott [22] also found a soluble activation factor that was localized entirely to the cytosolic fraction with a mass of approximately $40 \mathrm{kDa}$. Later studies confirmed the exact molecular weight to be $47 \mathrm{kDa}$ (p47phox).

In 1981, a variant or atypical X-linked form of CGD was described [23] whereby the gp91phox subunit was found in normal levels but only able to function partially. Curnutte [24] suggested that these rare type of CGD cases were allelic variants and patients with this uncommon cytochrome- $\mathrm{b}_{558}$-positive X-linked form of CGD have been reported by others since $[25,26]$. Today, classical Xlinked CGD refers to cases where there is no respiratory burst activity demonstrable in a patient's neutrophils and the gp91phox subunit is absent. Autosomal recessive CGD is diagnosed when burst activity is abnormal and one of the other NADPH oxidase subunits is deficient. Variant or atypical CGD is diagnosed when a patient's neutrophils have demonstrable amounts of NADPH oxi- 
dase subunit present but oxidaitive burst activity is not at a level sufficient to fight off infection.

In 1986, the gp91phox subunit was first cloned [27], encoded from the CYBB gene, although little homology with other known protein sequences shed inadequate light on its function at the time. This was a huge advance in the molecular understanding of CGD and led to the development of animal models and the ability to determine what controls gp91phox function and activity; as well as being fundamental to current gene therapy development. Subsequently, by screening a promyelocytic leukemia cDNA library, Volpp et al. (1989) cloned and sequenced a cDNA encoding the 47-kD component of the NADPH oxidase system [28], Leto et al. (1990) [29] cloned a p67phox cDNA while Dinauer et al. [30] reported the structure of the gene for the $22-\mathrm{kD}$ light chain of cytochrome- $\mathrm{b}_{558}$ and its chromosomal location, which served as a foundation for the analysis of genetic abnormalities at this locus in CGD. The cloning of p40phox by Wientjes et al. [31] provided important insights into its interactions with p67phox and p47phox in the cytosol. It was first suspected in the late 1980s that a GTPase might play a role in NADPH oxidase activation when it was demonstrated that guanine nucleotides were able to stimulate oxidase activity. The GTPase was subsequently identified and cloned as Rac1 or Rac 2 and it is now clear that its presence is absolutely required for full oxidase function [32].

\section{Mutations in the $X$-linked and autosomal recessive forms of CGD}

Research into CGD has improved our knowledge of the normal NADPH oxidase system. In some cases, the identification of specific mutations has provided insights at a molecular level. Most patients with CGD have mutations in the CYBB gene that encodes gp91phox, located at Xp21.1. Since the discovery of the CYBB gene no single mutation appeared to be responsible and a flood of research on mutations ensued, reporting large and small deletions, frameshifts and other mutations. The genetics of many hundreds of families with CGD were investigated and recounted and a mutation registry database for $\mathrm{X}$ linked and autosomal recessive CGD was set up by Dirk Roos and MaunoVihinen from the University of Tampere in Finland [33] which presently lists 304 mutation entries from 267 unrelated families showing about 204 unique molecular events. Most of the X-linked mutations (174) are in the $\mathrm{N}$-terminal domain. The number of mutations in other domains report: 50 in the FAD domain, 49 in the NADPH domain, 7 in the loop region, 3 in the upstream, the non-coding region before initiation codon, and 20 undefined gross deletions. The most common mutations are nonsense mutations (81), followed by missense mutations (78), frameshift deletions (42), intron mutations (34), frameshift insertions (30), and inframe deletions (6) $[33,34]$.

Autosomal recessive CGD arises from mutations occurring in either the p67phox, $\mathrm{p} 47$ phox or $\mathrm{p} 21$ phox phagocyte oxidase proteins. Mutations in the NCF2 gene which encodes the p67phox represents about 5\% of CGD cases whereas deficiencies of NCF1 which encodes p47phox represents about a quarter of all cases of CGD [35]. Unlike other CGD subtypes, in which there is great heterogeneity among mutations, $97 \%$ of affected alleles in patients with p47phox deficiency carry a characteristic 2-base pair deltaGT deletion in the NCF1 gene [36]. p22phox mutations are less common and 2 novel nonsense and missense mutations in the CYBA gene have been described [37]. Mutations in the corresponding genes responsible for the different genetic subgroups of CGD are shown in Table 1. Genetic defects in Rap1a, Rac, or p40phox havenot been reported in CGD [38], however, a dominant-negative mutation in the hematopoietic-specific Rac2 GTPase was identified in an infant with severe neutrophil dysfunction and a predisposition to bacterial infections similar to CGD and leukocyte adhesion deficiency [39].

\section{Activation of the NADPH oxidase complex}

The dormant oxidase consists of both cytosolic and membrane-bound components, but the active $\mathrm{O} 2-$ - generating complex is confined to the plasma membrane $[1,2]$. This implies that the cytosolic components must either act in a signaling capacity by modifying the membrane components, or that they must become directly associated with the membrane via a translocation process.

The $47 \mathrm{kDa}$ phosphoprotein was found in both the cytosol and membranes after stimulation of neutrophils with phorbol myristate acetate and the phosphoprotein

Table I: Classification of CGD subunits.

\begin{tabular}{ccc}
\hline CGD gene & Genetic Transmission & Frequency (\%) \\
\hline gP9lphox (CYBB) & X-linked & 65 \\
P47phox (NCFI) & Autosomal recessive & 25 \\
p67phox (NCF2) & Autosomal recessive & 5 \\
P22phox (CYBA) & Autosomal recessive & 5 \\
\hline
\end{tabular}

Mutations can occur in one of four NADPH oxidase subunits which give rise to $X$-linked or autosomal recessive CGD. The approximate frequencies of case occurrence are shown, with figures extrapolated from Clark et al. [35] and Dineaur et al.[38]. 
was detected in the cytosol preceding its detection in membranes [40]. Activation of the neutrophil oxidase system appeared to be dependent upon phosphorylation of the cytosolic $47 \mathrm{kDa}$ protein [41], and incomplete phosphorylation was found to lead to failure of the subunit to translocate to the membrane for interaction with other membrane components of the oxidase. In intact neutrophils it was conclusively demonstrated that both p47phox and p67phox translocate to the membrane during activation of the respiratory burst [42]. This translocation was also normal in the variant $\mathrm{X}$-linked form of CGD in which cytochrome- $\mathrm{b}_{558}$ is present but does not transfer electrons, demonstrating that the absence of translocation in other forms of CGD is not a secondary effect of the failure to generate O2-- [43]. Ding and colleagues [44] were unable to detect any alterations in the protein kinases in CGD neutrophils that could explain these defects in phosphorylation of $\mathrm{p} 47$ phox. The GTP-binding protein Rac2 was also found to migrate from the cytosol to the membrane cytoskeleton with p67phox and p47phox, indicating that Rac2 behaves like a dedicated component of the respiratory burst oxidase [45]. A schematic of NADPH oxidase activation is shown in Figure 1.
The primary biochemical defect in CGD that leads to impaired microbicidal activity was thought to be failure of phagocytes to generate sufficient quantities of reactive oxygen species (ROS), which are responsible for the socalled respiratory or oxidative burst. These compounds are derived from initial production of the extremely unstable and weakly bactericidal $\mathrm{O} 2-\cdot$, which subsequently is dismutated into $\mathrm{H}_{2} \mathrm{O}_{2}$., In the presence of myloperoxidase which is delivered by primary granules into the phagosomes, $\mathrm{H}_{2} \mathrm{O}_{2}$ gives rise to more potent oxidants such as oxyhalides (most frequently hypochlorous acid), the hydroxyl radical (OH-), or singlet oxygen $\left(\mathrm{O}^{-} \cdot\right)^{-}$[46]. The high concentrations of ROS generated within the phagosome were thought to kill directly because of their oxidizing capacity.

The fact that phagocytes kill microbes through toxic oxygen radicals and their metabolites provided much of the biological basis for theories relating the toxicity of oxygen radicals to the pathogenesis of CGD. However, recent evidence [47] indicates that microbes might be killed by proteases, activated by the oxidase through the generation of a hypertonic, $\mathrm{K}^{+}$-rich and alkaline environment in the

\section{NADPH OXIDASE ACTIVATION}

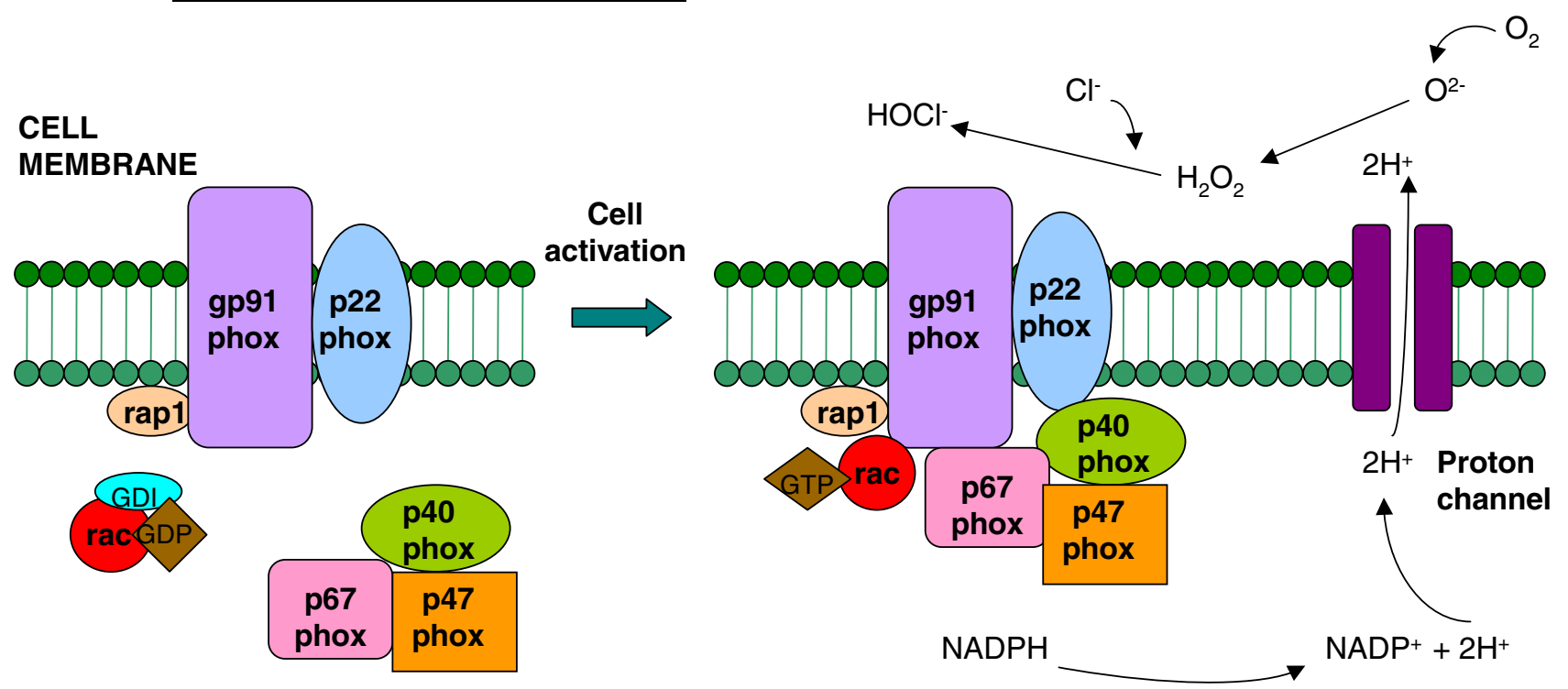

\section{CYTOSOL}

\section{Figure I}

Schematic representation of the NADPH oxidase enzyme. The integral membrane of the phagocyte consists of two subunits: p22phox and gp9 I phox which respectively produce the smaller and larger chain of the cytochrome- $b_{558}$. Two cytosolic subunits: p67phox and p47phox; a p40phox accessory protein and a Rac-GTP binding protein then translocate to the cell membrane upon cell activation to form the NADPH oxidase complex which generates a respiratory burst. Superoxide can react to form hydrogen peroxide and hypochlorus acid, which together participate in bacterial killing. 
phagocytic vacuole. Thus, the role of ROS in the killing process is not as direct as previously thought, although, ROS are necessary to increase phagosomal osmolarity. Mice made deficient in neutrophil-granule proteases, but normal in respect of superoxide production and iodinating capacity, were unable to resist staphylococcal and candidal infections, suggesting that proteases are primarily responsible for the destruction of the bacteria [48]. Further research then showed that microbial killing and digestion were abolished when the $\mathrm{BK}_{\mathrm{Ca}}$ channel was blocked, revealing an essential and unexpected function for this $\mathrm{K}^{+}$channel in the microbicidal process [48].

\section{Defective inflammatory responses}

In addition to recurrent life-threatening infections, patients often develop sterile granulomas in hollow organs, liver, lymphoid tissue and skin, without clinical evidence of infections [49]. The mechanisms involved in this aberrant inflammatory response are unknown. Inflammatory responses are finely balanced between proinflammatory and anti-inflammatory mediators and are important in generating an effective primary immune response and in clearing infection. Cultured cells from CGD patients have been shown to be deficient in their ability to produce anti-inflammatory mediators [50] and that neutrophils from these patients are defective in their ability to expose phosphatidylserine (PS), which is a recognition factor for phagocytic cells to clear apoptotic cell bodies. The externalized PS molecules on apoptotic cells, and subsequent internalization and degradation of apoptotic cells, is crucial to prevent the activation of an inflammatory response and persistence of inflammatory cells that do not undergo apoptosis and are not phagocytosed leads to an increase of necrosis and release of toxic granule contents that can cause chronic inflammation. Recently, we have shown that the rate of phagocytosis of apoptotic CGD neutrophils is also reduced (unpublished observations). It is not known why this occurs and further studies of the mechanisms of neutrophil apoptosis are necessary to understand the pathophysiology of its deficiency in CGD. Failure to successfully resolve inflammation can underlie the persistent inflammatory responses in CGD patients, as manifested by colitis, urinary tract obstruction, dysphagia, gastric outlet obstruction and chorioretinitis.

\section{Interferon-gamma therapy for CGD}

In the late 1980s the potential of interferon gamma was investigated as a prophylactic therapeutic agent for CGD as preliminary studies in CGD patients demonstrated that brief in vitro or in vivo administration of recombinant IFN- $\gamma($ rIFN- $\gamma$ ) significantly enhanced phagocyte O2-- production and Staphylococcus aureus bacterial killing. In two patients with variant X-linked CGD, rIFN- $\gamma$ treatment in vivo was also associated with increased spectral levels of neutrophil cytochrome- $b_{558}$ [51]. Subsequent studies found little evidence for transient increases in $\mathrm{O} 2-$ production following rIFN- $\gamma$ therapy, where O2-- production was not sustained or associated with any change in cytochrome- $b_{558}$ levels [52]. In some patients, rIFN- $\gamma$ therapy was associated with the appearance of a small subset of circulating monocytes (1\% to $20 \%$ ) that were NBT-positive, suggesting that one possible mechanism by which rIFN $-\gamma$ may benefit CGD patients was by partially correcting the respiratory burst defect in a subset of monocytes. Although it seemed that rIFN- $\gamma$ therapy in the vast majority of CGD patients was not due to enhanced neutrophil NADPH oxidase activity, the mechanism of rIFN- $\gamma$ action in CGD patients remains unknown. A study by Ahlin et al. [53] showed that rIFN- $\gamma$ treatment of patients with CGD was associated with augmented production of nitric oxide by polymorphonuclear neutrophils. A comprehensive follow up study of 76 patients with CGD who received rIFN$\gamma$ found that its prolonged use in patients with CGD appeared to be safe and showed persistent reduction in the frequency of serious infection and mortality [54]. Recent studies looking at the cytochrome- $\mathrm{b}_{558}$ gene expression in Brazil [55] and Japan [56] found increased total messenger RNA (mRNA) levels in the CGD patients' cells suggesting that rIFN- $\gamma$ improved mRNA splicing and concluded that rIFN- $\gamma$ partially corrects a nuclear processing defect. These studies have lead to the consensus that only rare variants with splice site mutations can be improved with rIFN- $\gamma$ therapy. rIFN- $\gamma$ therapy is relatively expensive due to the high cost of recombinant human interferons, the large doses and lengthy course of administration necessary to achieve maximum response rates in recipients, and is not routinely administered prophylactically in Europe.

\section{A cure for CGD}

Following the successful use of allogeneic bone marrow transplants to treat children with severe combined immune deficiency [57]. Goudemand and colleagues [58] made the first attempt to treat a case of CGD using bone marrow transplantation (BMT). Although in this case the transplant failed after two months due to tissue rejection recent advances in BMT expertise and technology have led to BMT becoming a successful treatment option for CGD patients. A recent review of cases revealed that 20 of 24 CGD patients are alive and disease free 1-7 years after transplant [59]. BMT can be successfully performed for CGD and remains an attractive option for children who have an HLA matched sibling donor and useful in selected very severe cases in which prophylactic therapy is problematic, although in many cases donors can be hard to find.

Gene therapy involves the permanent genetic correction of hematopoietic stem cells in which a vector is used to 
carry the corrective gene into the cells which are then reintroduced to the body. CGD is a particularly good candidate for gene therapy because low levels of functional phagocytes are expected to provide significant activity against pathogenic microbes. In 1992, Thrasher and colleagues [60] used cell lines from patients with defective p47phox as targets for reconstitution using retrovirusmediated gene transfer, thus creating an in vitro model of gene therapy for this disease. This was shortly followed by retrovirus-mediated gene transfer of gp91phox cDNA from patients with X-linked CGD to reconstitute functional NADPH oxidase activity in B-cell lines [61]. The reconstitution of NADPH oxidase activity in cell lines from three unrelated patients, each of which had a different molecular defect in the gene, suggested that X-CGD would be a suitable disease for treatment by gene therapy. CGD mouse models have been developed by gene disruption, and preclinical studies on these animals using recombinant retroviral vectors have demonstrated reconstitution of functionally normal neutrophils and increased resistance to pathogens such as Aspergillus fumigatus, Burkholderia cepacia and Staphylococcus aureus [62]. These studies were extended to human cell lines, where retroviral vectors to restore NADPH oxidase activity was tested in human myeloid leukemic cell lines defective in superoxide production, as well as in primary CD34+ cells obtained from X-CGD patients. It was shown that the level of $\mathrm{O} 2-$ - production in phagocytes derived from transduced cells was $69 \%$ of normal levels [63]. In the US, CGD gene therapy clinical trials targeted both the most common X-linked form of CGD as well as the autosomal recessive forms of this disease. Malech and colleagues [64] isolated hematopoietic stem cells from four X-CGD patients, infected the cells with a retrovirus containing the normal gp91phox gene, grew the transfected cells in culture, and infused them back into the original patients from which the cells were derived. Three of the four patients had sustained and continuous production of low levels of reconstituted neutrophils for 6 to 14 months. Of even greater interest, although still not understood, is the finding that two of the patients who had liver infections that resisted cure by conventional methods resolved during the course of treatment [64]. This suggests that the gene therapy approach could also be effective in treating CGD patients with severe intractable infections, although more targeted and longer term studies are needed.

Gene therapy trials for CGD in Europe began in 2004 through the collaborative efforts in Frankfurt and London. So far, two patients have been treated with retroviral vector and encouraging results show that both patients have significant levels of gene corrected cells and are clinically well (personal communication). Gene therapy holds great promise as an alternative treatment for patients without suitable marrow donors or where BMT is not a viable treatment option.

\section{Prospectives}

It is estimated that one in 250,000 babies is born with CGD, although symptoms of the condition may not appear until after the first few months of age. Early reports documented the survival of patients beyond 7 years of age as $21 \%$ [65] which has since vastly improved due to advancement in treatments, and use of prophylactic antibacterials has seen a significant reduction in infectious complications. Over the last decade there has been momentous progress in scientific research into the underlying mechanisms of CGD. A recent search on the NIH Pubmed database showed over 2500 scientific publications on CGD dating back as far as 1959. The European CGD registry (funded by the CGD Research Trust) currently contains data on 490 CGD patients that provides a wealth of information for scientists, clinicians, nurses and patients alike. In the UK, the CGD Research Trust and Support Group is an active group who monitor and support CGD patients based in Britain, in addition to raising money and funding research into CGD [66]. Improved diagnosis ensures that patients with CGD are effectively managed and many people with CGD can carry on a normal life with few problems.

\section{Declaration of competing interests}

The author(s) declare that they have no competing interests.

\section{Acknowledgements}

I would like to extend thanks to David Goldblatt and Adrian Thrasher from the Institute of Child Health and Great Ormond Street Hospital and Susan Walsh from the UK CGD Research Trust for their comments on this manuscript.

\section{References}

I. Janeway CA, Craig J, Davidson M, Downey W, Gitlin D, Sullivan JC: Hypergammaglobulinemia associated with severe, recurrent and chronic non-specific infection. Am J Dis Child 1954, 88:388-392.

2. Bridges RA, Berendes $\mathrm{H}$, Good RA: A fatal granulomatous disease of childhood; the clinical, pathological, and laboratory features of a new syndrome. AMA J Dis Child 1959, 97(4):387-408.

3. Landing BH, Shirkey HS: A syndrome of recurrent infection and infiltration of viscera by pigmented lipid histiocytes. Pediatrics 1957, 20(3):43I-438.

4. Quie PG, White JG, Holmes B, Good RA: In vitro bactericidal capacity of human polymorphonuclear leukocytes: diminished activity in chronic granulomatous disease of childhood. J Clin Invest 1967, 46(4):668-679.

5. Holmes B, Quie PG, Windhorst DB, Good RA: Fatal granulomatous disease of childhood. An inborn abnormality of phagocytic function. Lancet 1966, I(7449): | 225-I 228.

6. Macfarlane PS, Speirs AL, Sommerville RG: Fatal granulomatous disease of childhood and benign lymphocytic infiltration of the skin (congenital dysphagocytosis). Lancet 1967, I(7487):408-4I 0.

7. Quie PG, Kaplan EL, Page AR, Gruskay FL, Malawista SE: Defective polymorphonuclear-leukocyte function and chronic granulo- 
matous disease in two female children. $N$ Engl J Med 1968, 278(18):976-980

8. Azimi PH, Bodenbender JG, Hintz RL, Kontras SB: Chronic granulomatous disease in three female siblings. Jama 1968, 206(13):2865-2870.

9. Baehner RL, Nathan DG: Leukocyte oxidase: defective activity in chronic granulomatous disease. Science 1967, I 55(764):835-836.

10. Baehner RL, Nathan DG: Quantitative nitroblue tetrazolium test in chronic granulomatous disease. N Engl J Med 1968 278(18):97I-976.

II. Baehner RL, Karnovsky ML: Deficiency of reduced nicotinamideadenine dinucleotide oxidase in chronic granulomatous disease. Science 1968, 162(859): 1277-1279.

12. Kaplan EL, Laxdal T, Quie PG: Studies of polymorphonuclear leukocytes from patients with chronic granulomatous disease of childhood: bactericidal capacity for streptococci. Pediatrics 1968, 4I(3):59I-599.

13. Curnutte JT, Whitten DM, Babior BM: Defective superoxide production by granulocytes from patients with chronic granulomatous disease. N Engl J Med I 974, 290(I I):593-597.

14. Hohn DC, Lehrer RI: NADPH oxidase deficiency in X-linked chronic granulomatous disease. I Clin Invest 1975, 55(4):707-7। 3.

15. Johnston RBJ, Keele BBJ, Misra HP, Lehmeyer JE, Webb LS, Baehner $\mathrm{RL}$, Rajagopalan $\mathrm{KV}$ : The role of superoxide anion generation in phagocytic bactericidal activity. Studies with normal and chronic granulomatous disease leukocytes. J Clin Invest 1975, 55(6): $1357-1372$

16. Segal AW, Jones OT: Neutrophil cytochrome b in chronic granulomatous disease. Lancet 1979, I (8 I 24): 1036-1037.

17. Segal AW, Cross AR, Garcia RC, Borregaard N, Valerius NH, Soothill JF, Jones OT: Absence of cytochrome b-245 in chronic granulomatous disease. A multicenter European evaluation of its incidence and relevance. N Engl J Med I983, 308(5):245-25I.

18. Borregaard N, Heiple JM, Simons ER, Clark RA: Subcellular localization of the b-cytochrome component of the human neutrophil microbicidal oxidase: translocation during activation. J Cell Biol 1983, 97(I):52-6I.

19. Baehner RL, Kunkel LM, Monaco AP, Haines JL, Conneally PM, Palmer C, Heerema N, Orkin SH: DNA linkage analysis of $\mathbf{X}$ chromosome-linked chronic granulomatous disease. Proc Natl Acad Sci USA 1986, 83(10):3398-340I.

20. Segal AW: Absence of both cytochrome b-245 subunits from neutrophils in $\mathrm{X}$-linked chronic granulomatous disease. Nature 1987, 326(6 I 08):88-91.

21. Umei T, Takeshige K, Minakami S: NADPH-binding component of the superoxide-generating oxidase in unstimulated neutrophils and the neutrophils from the patients with chronic granulomatous disease. Biochem J 1987, 243(2):467-472.

22. Curnutte JT, Kuver R, Scott PJ: Activation of neutrophil NADPH oxidase in a cell-free system. Partial purification of components and characterization of the activation process. J Biol Chem 1987, 262(1 2):5563-5569.

23. Lew PD, Southwick FS, Stossel TP, Whitin JC, Simons E, Cohen HJ: A variant of chronic granulomatous disease: deficient oxidative metabolism due to a low-affinity NADPH oxidase. N Engl J Med 1981, 305(22): 1329-1333.

24. Curnutte JT: Classification of chronic granulomatous disease. Hematol Oncol Clin North Am 1988, 2(2):241-252.

25. Okamura N, Malawista SE, Roberts RL, Rosen H, Ochs HD, Babior BM, Curnutte JT: Phosphorylation of the oxidase-related 48K phosphoprotein family in the unusual autosomal cytochrome-negative and $\mathbf{X}$-linked cytochrome-positive types of chronic granulomatous disease. Blood 1988, 72(2):8I I-816.

26. Bolscher BG, de Boer M, de Klein A, Weening RS, Roos D: Point mutations in the beta-subunit of cytochrome b558 leading to X-linked chronic granulomatous disease. Blood I991, 77(II):2482-2487.

27. Royer-Pokora B, Kunkel LM, Monaco AP, Goff SC, Newburger PE, Baehner RL, Cole FS, Curnutte JT, Orkin SH: Cloning the gene for the inherited disorder chronic granulomatous disease on the basis of its chromosomal location. Cold Spring Harb Symp Quant Biol 1986, 5 I Pt I: I77-I83.

28. Volpp BD, Nauseef WM, Donelson JE, Moser DR, Clark RA: Cloning of the cDNA and functional expression of the 47-kilodalton cytosolic component of human neutrophil respiratory burst oxidase. Proc Natl Acad Sci U S A 1989, 86(18):7195-7I 99.

29. Leto TL, Lomax KJ, Volpp BD, Nunoi H, Sechler JM, Nauseef WM, Clark RA, Gallin Jl, Malech HL: Cloning of a 67-kD neutrophil oxidase factor with similarity to a noncatalytic region of p60csrc. Science 1990, 248(4956):727-730.

30. Dinauer MC, Pierce EA, Bruns GA, Curnutte JT, Orkin SH: Human neutrophil cytochrome b light chain (p22-phox). Gene structure, chromosomal location, and mutations in cytochromenegative autosomal recessive chronic granulomatous disease. J Clin Invest 1990, 86(5): 1729-1737.

31. Wientjes FB, Hsuan JJ, Totty NF, Segal AW: p40phox, a third cytosolic component of the activation complex of the NADPH oxidase to contain src homology 3 domains. Biochem J 1993, 296 ( Pt 3):557-56I.

32. Didsbury J, Weber RF, Bokoch GM, Evans T, Snyderman R: rac, a novel ras-related family of proteins that are botulinum toxin substrates. J Biol Chem 1989, 264(28): 16378-16382

33. Roos D, Curnutte JT: CGD Registary Mutation Database [http://bioinf.uta.fi/CYBBbase/]. 2003.

34. Riikonen $P$, Vihinen M: MUTbase: maintenance and analysis of distributed mutation databases. Bioinformatics 1999 , I 5( I 0):852-859.

35. Clark RA, Malech HL, Gallin JI, Nunoi H, Volpp BD, Pearson DW, Nauseef WM, Curnutte JT: Genetic variants of chronic granulomatous disease: prevalence of deficiencies of two cytosolic components of the NADPH oxidase system. N Engl J Med I989, 32 I (I0):647-652.

36. Noack D, Rae J, Cross AR, Ellis BA, Newburger PE, Curnutte JT, Heyworth PG: Autosomal recessive chronic granulomatous disease caused by defects in NCF-I, the gene encoding the phagocyte p47-phox: mutations not arising in the NCF-I pseudogenes. Blood 200I, 97(I):305-3II

37. Yamada M, Ariga T, Kawamura N, Ohtsu M, Imajoh-Ohmi S, Ohshika E, Tatsuzawa O, Kobayashi K, Sakiyama Y: Genetic studies of three Japanese patients with p22-phox-deficient chronic granulomatous disease: detection of a possible common mutant CYBA allele in Japan and a genotype-phenotype correlation in these patients. BrJ Haematol 2000, 108(3):5 I I-5I 7 .

38. Dinauer MC: Chronic granulomatous disease and other disorders of phagocyte function. Hematology (Am Soc Hematol Educ Program) 2005:89-95.

39. Ambruso DR, Knall C, Abell AN, Panepinto J, Kurkchubasche $A$, Thurman G, Gonzalez-Aller C, Hiester A, deBoer M, Harbeck RJ, Oyer R, Johnson GL, Roos D: Human neutrophil immunodeficiency syndrome is associated with an inhibitory Rac2 mutation. Proc Natl Acad Sci U S A 2000, 97(9):4654-4659.

40. Heyworth PG, Shrimpton CF, Segal AW: Localization of the 47 $\mathrm{kDa}$ phosphoprotein involved in the respiratory-burst NADPH oxidase of phagocytic cells. Biochem J 1989, 260(I):243-248.

41. Rotrosen D, Leto TL: Phosphorylation of neutrophil 47-kDa cytosolic oxidase factor. Translocation to membrane is associated with distinct phosphorylation events. J Biol Chem 1990, 265(32): 19910-19915.

42. Clark RA, Volpp BD, Leidal KG, Nauseef WM: Two cytosolic components of the human neutrophil respiratory burst oxidase translocate to the plasma membrane during cell activation. I Clin Invest 1990, 85(3):7|4-72I.

43. Heyworth PG, Curnutte JT, Nauseef WM, Volpp BD, Pearson DW, Rosen H, Clark RA: Neutrophil nicotinamide adenine dinucleotide phosphate oxidase assembly. Translocation of $\mathrm{p} 47$. phox and p67-phox requires interaction between $\mathrm{p} 47$-phox and cytochrome b558. I Clin Invest |99|, 87(I):352-356.

44. Ding J, Badwey JA, Erickson RW, Balazovich KJ, Curnutte JT: Protein kinases potentially capable of catalyzing the phosphorylation of p47-phox in normal neutrophils and neutrophils of patients with chronic granulomatous disease. Blood 1993, 82(3):940-947.

45. el Benna J, Ruedi JM, Babior BM: Cytosolic guanine nucleotidebinding protein Rac2 operates in vivo as a component of the neutrophil respiratory burst oxidase. Transfer of Rac2 and the cytosolic oxidase components p47phox and p67phox to the submembranous actin cytoskeleton during oxidase activation. J Biol Chem 1994, 269(9):6729-6734. 
46. Meischl C, Roos D: The molecular basis of chronic granulomatous disease. Springer Semin Immunopathol 1998, 19(4):4I7-434.

47. Ahluwalia J, Tinker A, Clapp LH, Duchen MR, Abramov AY, Pope S, Nobles M, Segal AW: The large-conductance Ca2+-activated K+ channel is essential for innate immunity. Nature 2004, 427(6977):853-858.

48. Reeves EP, Lu H, Jacobs HL, Messina CG, Bolsover S, Gabella G Potma EO, Warley A, Roes J, Segal AW: Killing activity of neutrophils is mediated through activation of proteases by $\mathrm{K}+$ flux. Nature 2002, 4I6(6878):29I-297.

49. Segal AW: The NADPH oxidase and chronic granulomatous disease. Mol Med Today 1996, 2(3): 129-135.

50. Brown JR, Goldblatt D, Buddle J, Morton L, Thrasher AJ: Diminished production of anti-inflammatory mediators during neutrophil apoptosis and macrophage phagocytosis in chronic granulomatous disease (CGD). J Leukoc Biol 2003, 73(5):59|-599.

5I. Ezekowitz RA, Orkin SH, Newburger PE: Recombinant interferon gamma augments phagocyte superoxide production and $X$ chronic granulomatous disease gene expression in $\mathbf{X}$-linked variant chronic granulomatous disease. J Clin Invest 1987, 80(4): $1009-1016$.

52. Woodman RC, Erickson RW, Rae J, Jaffe HS, Curnutte JT: Prolonged recombinant interferon-gamma therapy in chronic granulomatous disease: evidence against enhanced neutrophil oxidase activity. Blood I992, 79(6): |558-|562.

53. Ahlin A, Larfars G, Elinder G, Palmblad J, Gyllenhammar H: Gamma interferon treatment of patients with chronic granulomatous disease is associated with augmented production of nitric oxide by polymorphonuclear neutrophils. Clin Diagn Lab Immunol 1999, 6(3):420-424.

54. Marciano BE, Wesley R, De Carlo ES, Anderson VL, Barnhart LA, Darnell D, Malech HL, Gallin JI, Holland SM: Long-term interferongamma therapy for patients with chronic granulomatous disease. Clin Infect Dis 2004, 39(5):692-699.

55. Condino-Neto A, Newburger PE: Interferon-gamma improves splicing efficiency of CYBB gene transcripts in an interferonresponsive variant of chronic granulomatous disease due to a splice site consensus region mutation. Blood 2000, 95(I I):3548-3554.

56. Ishibashi F, Mizukami T, Kanegasaki S, Motoda L, Kakinuma R, Endo F, Nunoi $\mathrm{H}$ : Improved superoxide-generating ability by interferon gamma due to splicing pattern change of transcripts in neutrophils from patients with a splice site mutation in CYBB gene. Blood 200I, 98(2):436-44I.

57. Flad HD, Stein G, Haas RJ, Niethammer D, Goldmann SF, Dietrich M: Transplantation of a patient with severe combined immunodeficiency (SCID) with bone marrow from the MLC identical donor: some immunobiological aspects [proceedings]. Z Immunitatsforsch Immunobiol 1976, I 52(4):330-334.

58. Goudemand J, Anssens R, Delmas-Marsalet Y, Farriaux JP, Fontaine G: [Attempt to treat a case of chronic familial granulomatous disease by allogenic bone marrow transplantation]. Arch $\mathrm{Fr}$ Pediatr 1976, 33(2): | 2 |- 129.

59. Del Giudice I, lori AP, Mengarelli A, Testi AM, Romano A, Cerretti R, Macri F, lacobini M, Arcese W: Allogeneic stem cell transplant from HLA-identical sibling for chronic granulomatous disease and review of the literature. Ann Hematol 2003, 82(3): $189-192$.

60. Thrasher A, Chetty M, Casimir C, Segal AW: Restoration of superoxide generation to a chronic granulomatous diseasederived B-cell line by retrovirus mediated gene transfer. Blood 1992, 80(5): I I25-II 29.

61. Porter CD, Parkar MH, Levinsky RJ, Collins MK, Kinnon C: X-linked chronic granulomatous disease: correction of NADPH oxidase defect by retrovirus-mediated expression of gp 9 I-phox. Blood 1993, 82(7):2196-2202.

62. Goebel WS, Dinauer MC: Retroviral-mediated gene transfer and nonmyeloablative conditioning: studies in a murine $X$ linked chronic granulomatous disease model. J Pediatr Hematol Oncol 2002, 24(9):787-790.

63. Grez M, Becker S, Saulnier S, Knoss H, Ott MG, Maurer A, Dinauer MC, Hoelzer D, Seger R, Hossle JP: Gene therapy of chronic granulomatous disease. Bone Marrow Transplant 2000, 25 Suppl 2:S99-104.
64. Malech HL, Choi U, Brenner S: Progress toward effective gene therapy for chronic granulomatous disease. Jpn J Infect Dis 2004, 57(5):S27-8.

65. Johnston RBJ, McMurry JS: Chronic familial granulomatosis. Report of five cases and review of the literature. Am J Dis Child 1967, I I 4(4):370-378.

66. UK CGD Research Trust and Support Group [http:// www.cgd.org.uk/].
Publish with Biomed Central and every scientist can read your work free of charge

"BioMed Central will be the most significant development for disseminating the results of biomedical research in our lifetime. "

Sir Paul Nurse, Cancer Research UK

Your research papers will be:

- available free of charge to the entire biomedical community

- peer reviewed and published immediately upon acceptance

- cited in PubMed and archived on PubMed Central

- yours - you keep the copyright 